\title{
コンクリートのひびわれ界面に関する構成方程式と 基本 4 係数の同定 \\ A CONSTITUTIVE EQUATION OF A SINGLE CRACK IN CONCRETE AND IDENTIFICATION OF FOUR BASIC COEFFICIENTS
}

\author{
吉川弘道* ・吳 智 深** ・田辺忠顕*** \\ By Hiromichi YOSHIKAWA, Zhishen WU and Tada-aki TANABE
}

\begin{abstract}
The authors proposed a constitutive equation that relates relative displacements and applied stresses on cracked surfaces of concrete in the plane stress state ${ }^{6)}$.

In the paper, the four basic coefficients, such as the shear stiffness, the normal stiffness, the dilatancy ratio and the frictional coefficient, are identified making use of experimental results from the presently available literature.

The proposed model is then compared with the mechanical response of direct shear tests and reasonably good agreement is obtained.

Keywords : crack surface, constitutive equation, shear stiffness, normal stiffness, dilatancy ratio, frictional coefficient, identification, coupling effect
\end{abstract}

\section{1.はじめに}

ひびわれ界面に沿って，せん断力が伝達される場合， これによりせん断すべりが生じる一方で, ひびわれ幅の 開口やひびわれ直交方向の軸圧縮の増大が励起され，界 面の力学量すべてが影響し合う複雑な力学挙動を呈す る.ここで, $\sigma_{n}^{c}, \tau_{n t}^{c}$ をコンクリートのひびわれ界面に 生じる, ひびわれ垂直方向と接線方向の応力, また, $\delta_{n}$ (ひびわれ幅) と $\delta_{t}$ (すべり) をひびわれ界面での相 対的不連続変位量とすると (図一1), 二次元問題 (平面 応力）の場合，これら4量はひびわれに伴う非線形挙動 を記述する際の重要な力学的状態量となる（下添字 $n$, $t$ は,ひびわれ界面の法線方向 (normal) 亡接線方向 (tangential) を示し，これら 4 量を $n$ - $t$ 座標で定義す る. また，上添字 $c$ はコンクリートを意味する).

そして,ひびわれ解析においては，これらの界面応力 $\sigma_{n}^{c}, \tau_{n t}^{c}$ と不連続変位量 $\delta_{n}, \delta_{t}$ (これらを “界面の力学 4 量”之総称する）との構成関係を構築することが最も重

* 正会員 工博 武蔵工業大学講師 工学部土木工学科 ( ₹158 世田谷区玉堤 1-28-1)

** 学生会員 工修 名古屋大学大学院 工学部土木工学科 ( 个464 名古屋市千種区不老町)

*** 正会員 工博 名古屋大学教授 工学部土木工学科(同上)
要な要件である.

ひびわれ界面における特有の非線形現象については, 古くから個々に認知され，コンクリート構造・岩盤力学 の両分野で多くの議論が展開されてきた（ 1$)$ の 5 章, 2)，3）．たとえば，ひびわれ面の凹凹によるせん断伝 達 (shear transfer) や骨材のかみ合い効果 (aggregate interlock), または摩擦接触におけるクーロン則 (Coulomb criterion) の適用などがある.さらに，ひ びわれ面でのすべりに伴うひびわれ幅の開口（crack dilatancy) なよ゙も含め, その実験的 ${ }^{4)}$ ・解析的 ${ }^{5)}$ な研究 は数多くにのぼる.しかし，これらは別々に議論され， そのモデル化や実験式は個々に提示されるのみで, 統括 的に取り扱ったものは限られたものとなっている.

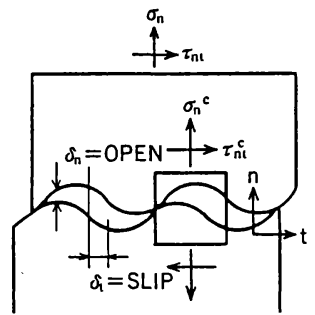

図一1 ひびわれ界面における応力 $\tau_{n t}^{c}, \sigma_{n}^{c}$ と 不連続変位 $\delta_{l}, \delta_{n}$ の定義 
そこで，著者らは，ひびわれ界面の非線形性を記述す る構成関係式を解析的に導出する ${ }^{6}$ とともに，実験結果 の取扱いおよび実験定数の同定に関する考察を行った。 本文では，導出した構成マトリックスに含まれる 4 個の 諸係数（せん断剛性, 垂直剛性, ダイレイタンシー比, 摩擦係数) を実験的に定め, 具体的な数式として提示し, 既報 ${ }^{6}$ の続報とするものである．加えて，実験結果との 比較を行い，せん断伝達のメカニズムについて考察する とともに, 提案モデルの予測精度を証査するものである.

\section{2. 構成方程式の導出}

著者らが既報6ににて提案した，ひびわれ界面の力学的 挙動に関する構成関係式の導出過程を以下のように要 約・再記する．まず，既往の実験結果を概観し，次のよ うな関係式を出発点とする。

$$
\begin{aligned}
& \delta_{t}=\delta_{t}\left(\tau_{n t}^{c}, \delta_{n}\right) \\
& \sigma_{n}^{c}=\sigma_{n}^{c}\left(\delta_{n}, \tau_{n t}^{c}\right)
\end{aligned}
$$

すなわち, 上式の第 1 式は, 1 つの変位成分 $(t$ 方向 $)$ を,同方向の応力成分と他方向の変位成分の関数として, 第 2 式は， 1 つの応力成分（ $n$ 方向）を同方向の変位成 分ともう一方の応力成分で表わしていることが特徴であ る.これらを，増分形式にするために，全微分をとると 下式が得られる.

$$
\left.\begin{array}{c}
d \delta_{t}=\frac{\partial \delta_{t}}{\partial \tau_{n t}^{c}} d \tau_{n t}^{c}+\frac{\partial \delta_{t}}{\partial \delta_{n}} d \delta_{n} \\
d \sigma_{n}^{c}=\frac{\partial \sigma_{n}^{c}}{\partial \delta_{n}} d \delta_{n}+\frac{\partial \sigma_{n}^{c}}{\partial \tau_{n t}^{c}} d \tau_{n t}^{c}
\end{array}\right\}
$$

ここで, 上式に含まれる偏導関数に対して，次式のよう な 4 つの諸係数を定義・導入する.

$$
\begin{aligned}
& k_{t} \equiv\left(\frac{\partial \delta_{t}}{\partial \tau_{n t}^{c}}\right)^{-1}, \quad k_{n} \equiv \frac{\partial \sigma_{n}^{c}}{\partial \delta_{n}} \cdots \\
& \mu_{f} \equiv\left(\frac{-\partial \sigma_{n}^{c}}{\partial \tau_{n t}^{c}}\right)^{-1}, \beta_{d} \equiv \frac{\partial \delta_{n}}{\partial \delta_{t}} \cdots
\end{aligned}
$$

$k_{t}$ はひびわれ界面でのせん断剛性, $k_{n}$ は垂直剛性, また, $\beta_{d}$ はダイレイタンシー比 (dilatancy ratio), $\mu_{f}$ は摩擦 係数（frictional coefficient）を表わす。これらを基本 4 係数と称し, 力学 4 量との関係を表一 1 に要約する.

基本 4 係数を式（2）に代入するとともに，マトリック ス表示すると最終的に次式を得る.

$$
\left\{\begin{array}{c}
d \tau_{n t}^{c} \\
d \sigma_{n}^{c}
\end{array}\right\}=k_{t}\left[\begin{array}{cc}
1 & -(1-\xi) \frac{1}{\beta_{d}} \\
-\frac{1}{\mu_{s}} & \frac{1}{\mu_{s} \beta_{d}}
\end{array}\right]\left\{\begin{array}{l}
d \delta_{t} \\
d \delta_{n}
\end{array}\right\} \cdots(5)
$$

\begin{tabular}{|c|c|c|}
\hline 界 面 4 量 & せん断応力 $\tau_{\mathrm{nt}}^{\mathrm{c}}$ & $\begin{array}{l}\text { 垂直変位 } \delta_{n}>0 \\
(\text { ひひわれ幅 ) }\end{array}$ \\
\hline $\begin{array}{c}\text { せん断変位 } \delta_{\mathrm{t}} \\
(す へ り り \text { 量) }\end{array}$ & せん断䣓性 $\mathrm{k}_{\mathrm{t}}$ & タイラタンシー比 $\beta_{\mathrm{d}}$ \\
\hline 垂直応力 $\sigma_{\mathrm{n}}^{\mathrm{c}}<0$ & 糜缐係数 & 垂直㣚性 $k_{n}$ \\
\hline
\end{tabular}

ただし

$$
\xi=\mu_{s} \beta_{d} \frac{k_{n}}{k_{t}}
$$

上式が，著者らの提案する二次元場におけるひびわれ界 面の構成方程式である。これによって, 従来から議論さ
表一1 界面の力学 4 量と基本 4 係数との相関関係

れてきたせん断伝達に加えて, クラック・ダイレイタン シーゃ Coulomb 摩擦などの交差効果 (coupling effect), ひびわれの開口・閉合などを 1 つの方程式で一括して表 現することが可能である，また，正定值（positive definite) に関する数学的要件も満足する.

そして, 式（5）に含まれる基本 4 係数 $k_{t}, k_{n}, \beta_{d}$, $\mu_{f}$ のモデル化・数式化を具体的に提示することにより, 本モデルは完遂するもので, これが本論文の目的である.

\section{3. 基本 4 係数のモデル化と同定}

基本 4 係数 $k_{t}, k_{n}, \beta_{d}, \mu_{s}$ は，そのときの状態量（界 面の力学 4 量) の関数であることはもちろん, 母材コン クリートの力学的特性（圧縮強度, 弾性係数など）に依 存し, ひびわれ面の粗度, 骨材の最大寸法にも影響する ことが認められ，さまざまな実験活動が行われている(文 献 1 ) の 5 章).

これまでの国内外の主要実験(4),9) 12),15),16) は，せん断 剛性のみに着目したものが多いが，一般的なモデル化に 至っているとはいいがたく, さらに, 垂直剛性 $k_{n}$, 交 差係数 $\mu_{f}, \beta_{d}$ に言及したものはほとんどないのが現状 である. したがって，上記の要件すべてを満たす材料モ デルを構築するには，さらに広範囲で系統的な実験研究 が必要となる.

そこで，3. では，著者らによる実験結果も含めて， 現在，入手し得る実験データのうちから，境界条件の明 瞭なものを抽出し, 基本 4 係数を実験的に同定するもの である.これらを以下(1) (3)に順次詳述するが, 基本 4 係数の仮定した曲線と得られた係数をあらかじめ表一2 に一括揭載する(本研究は, せん断伝達を主に考えてお り，これがまたきわめて複雑な非線形挙動を示すため, $k_{t}$ は基本 4 係数のうち最も多くのパラメーターを必要 とする複雑な実験式となっている).

(1) せん断剛性 $k_{t}$ のモデル化

ひびわれ界面のせん断剛性を与える接線係数 $k_{t}$ は, 式 (3) より,

$$
k_{t} \equiv\left(\frac{\partial \delta_{t}}{\partial \tau_{n t}^{c}}\right)^{-1}=\left.\frac{d \tau_{n t}^{c}}{d \delta_{t}}\right|_{\sigma_{n=\text { const. }}}
$$

で表わすことができることから，初期ひびわれ幅が一定 に保たれたときのせん断挙動について考える.この場合, 
いくつかのせん断実験結果によれば，初期にやや急激な すべり（free slip）があり，その後骨材のかみ合いによ り剛性が回復, 摩擦すべり（frictional slip）を生じ, やがて最大耐力に達するのが一般的である.

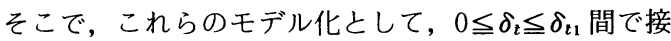
線剛性が徐々に増大 (interlocking) し， $\delta_{t}=\delta_{t 1}$ で最大 剛性 $K_{I S T}$ となり，その後剛性が低下し，やがて最大せ ん断力 $\tau_{u}$ に漸近する，次式のような双曲線関数を仮定 した(図一2参照).

$$
\begin{aligned}
& \tau_{n t}^{c}=\tau_{u} \cdot \frac{\tanh \left\{\frac{K_{0}}{\tau_{u}}\left(\delta_{t}-\delta_{t 1}\right)\right\}+q}{1+q} \\
& k_{t}=K_{I S T} \cdot \operatorname{sech}^{2}\left\{\frac{K_{0}}{\tau_{u}}\left(\delta_{t}-\delta_{t 1}\right)\right\} \cdots
\end{aligned}
$$

ここで,

$$
K_{0}=K_{I S T}(1+q), \quad q=\tanh \left(\frac{K_{0}}{\tau_{u}} \delta_{t 1}\right)
$$

$K_{I S T}$ は最大せん断剛性， $\delta_{t 1}$ はそのときのせん断変位， $\tau_{u}$ は最大せん断強度を表わす. $K_{0}, q$ は，これら 3 係数 から，式（10）により一義的に求まる（ただし，収束繰 返し計算を必要とする). すなわち，式 $(9)$ は， 3 パ ラメーター $\left(K_{I S T}, \delta_{t 1}, \tau_{u}\right)$ によって特徴づけられる双 曲線型のせん断変形モデルであるといえる.

この 3 パラメーターは, そのときのひびわれ幅 $\delta_{n}$ に 大きく依存することは多くの実験で明らかにされている が，これはまた材料特性值としての圧縮強度 $f_{c}$ と骨材 の最大寸法 $D_{a}$ にも影響を受けると考えられる. そこで, このような定性的特性を满足するように $\delta_{n}, f_{c}, D_{a}$ を影 響因子とする実験式を仮定する（表一2参照, 圧縮強度 については, $f_{c}=25 \mathrm{MPa}$, 骨材の最大寸法については, $D_{a}=16 \mathrm{~mm}$ を基準値としていることが同表から読み取 れよう). 表中に示したように, 最大剛性 $K_{I S T}$ には $a_{1}$ $\sim a_{4}$, そのときのすべり量 $\delta_{t 1}$ には $a_{5} \sim a_{8}$, 最大せん断 力 $\tau_{u}$ に対しては $a_{9} \sim a_{12}$ の合計 12 個の実験定数を必要 とする.これらを決定するため，既往の入手し得る実測
データのうち, 特に式 $(7)$ を満足するもの(すなわち, ひびわれ幅一定）を選び出し，同一図中にプロットする ことにより，実験定数の同定を行った.

まず，最大せん断剛性 $K_{I S T}$ は，著者らによる実験も

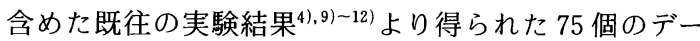
夕を用い, これらより回帰曲線を最小二乗法により算出 した (図一3). 図一3(a) は $a_{2}=0$ としコンクリート強 度の影響を無視した場合，(b) は $a_{2}=0.6$ としてこれ を考慮した場合である．同図より明らかに，(b) の方 がばらつきが少なく，不偏分散は，(a)で 0.121，(b) で 0.094 であり, コンクリート強度の影響を示すもので
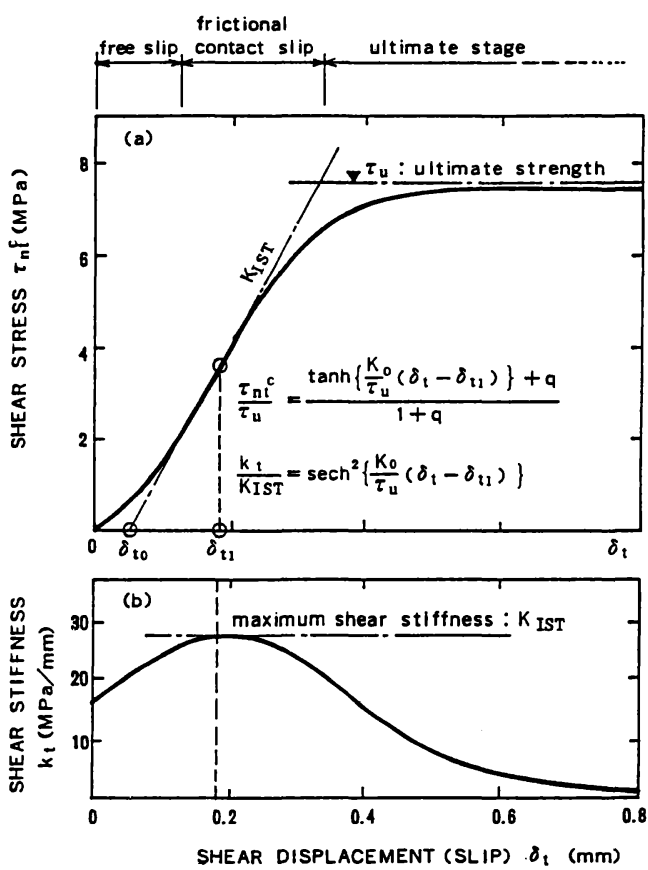

図一2 ひびわれ界面におけるせん断挙動のモデル化

(a) せん断応力 せん断変形の関係,

(b) せん断剛性のモデル化 $\left(\delta_{t 1}=0.18 \mathrm{~mm}, K_{I s r}=27 \mathrm{MPa} / \mathrm{mm}\right.$,

\begin{tabular}{|c|c|}
\hline SHEAR STIFFNESS $: \mathrm{k}_{\mathrm{t}}[\mathrm{MPa} / \mathrm{mm}]$ & CONSTANTS \\
\hline $\mathrm{K}_{\mathrm{t}}=\mathrm{K}_{\mathrm{IST}} \operatorname{sech}^{2}\left\{\frac{\mathrm{K}_{0}}{\tau_{\mathrm{u}}}\left(\delta_{\mathrm{t}}-\delta_{\mathrm{t} 1}\right)\right\}$ & \\
\hline$K_{\text {IST }}=a_{1}\left(\frac{f_{c}}{25}\right)^{a_{2}}\left(\frac{D_{a}}{16}\right)^{a_{3}} \delta_{n}^{-a_{4}}$ & $\begin{array}{l}a_{1}=3.74, a_{2}=0.60 \\
a_{1}=0, a_{4}=0.96\end{array}$ \\
\hline$\delta_{\mathrm{t} 1}=\mathrm{a}_{5}\left(\frac{f_{\mathrm{c}}}{25}\right)^{\mathrm{a}_{4}}\left(\frac{\mathrm{D}_{\mathrm{a}}}{16}\right)^{-\mathrm{a}_{\mathrm{r}}} \delta_{\mathrm{n}}^{\mathrm{a}_{\mathrm{c}}}$ & $\begin{array}{l}a_{s}=1.42, a_{6}=0 \\
a_{r}=1.20, a_{s}=1.31\end{array}$ \\
\hline$\tau_{u}=\tau_{0} \frac{a_{9}}{a_{10}+\left(\delta_{n} / D_{a}\right)^{a_{11}}}, \quad \tau_{0}=a_{12} f_{c}$ & $\begin{array}{l}a_{9}=a_{10}=0.01 \\
a_{11}=2\end{array}$ \\
\hline $\mathrm{K}_{0}=\mathrm{K}_{\mathrm{IST}}(1+\mathrm{q}), \quad \mathrm{q}=\tanh \left(\frac{\mathrm{K}_{0} \delta_{\mathrm{t1}}}{\tau_{\mathrm{u}}}\right)$ & $\begin{aligned} a_{12}= & =0.2 \sim 0.3 \\
& (0.245)\end{aligned}$ \\
\hline
\end{tabular}
$\tau_{u}=7.5 \mathrm{MPa}$ の場合)

\begin{tabular}{|c|c|}
\hline NORMAL STIFFNESS $: k_{n}[\mathrm{MPa} / \mathrm{mm}]$ & CONSTANTS \\
\hline $\mathrm{k}_{\mathrm{n}} / \mathrm{f}_{\mathrm{c}}=\mathrm{b}_{1} \mathrm{~b}_{2}\left(\boldsymbol{\delta}_{\mathrm{n}}-\beta_{\mathrm{d}} \delta_{\mathrm{t}}\right)^{-\left(\mathrm{b}_{2}+1\right)}$ & $\begin{array}{l}b_{1}=0.0082 \\
b_{2}=0.878\end{array}$ \\
\hline FRICTIONAL RATIO $: \mu_{i}$ & CONSTANTS \\
\hline $\boldsymbol{\mu}_{1}=c_{1} \mu_{0} \exp \left(c_{2} \delta_{n}\right)$ & $\begin{array}{l}\mu_{0}=1.16 \\
c_{1}=0.5 \sim 1.5 \\
c_{2}=0.61\end{array}$ \\
\hline DILATANCY RATIO $: \beta_{\mathrm{d}}$ & CONSTANTS \\
\hline$\beta_{\mathrm{d}}=c_{3} \beta_{0} \exp \left(-c_{4} \mid \frac{\sigma_{\mathrm{n}}^{\mathrm{c}}}{f_{\mathrm{c}}}\right)$ & $\begin{array}{l}\beta_{0}=1.64 \\
c_{3}=0.5 \sim 1.5 \\
c_{4}=6.42\end{array}$ \\
\hline
\end{tabular}

表一2 界面の基本 4 係数（ $\left.k_{\imath}, k_{n}, \mu_{f}, \beta_{d}\right)$ に関する提案曲線と 各定数の同定值 

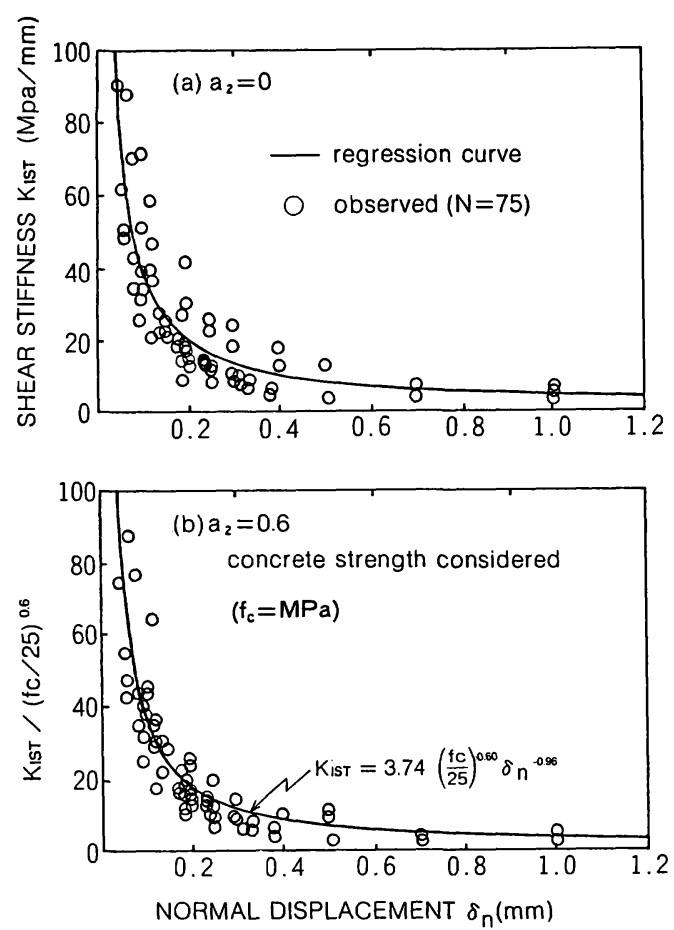

図一3 最大せん断剛性 $K_{I S T}$ に関する実験結果のまとめと最小 二乗近似による各係数の決定

ある.そして，回帰計算の結果 $K_{I S T}$ の実験式として下 式を得た.

$$
K_{I S T}=3.74\left(\frac{f_{c}}{25}\right)^{0.60} \delta_{n}^{-0.96}
$$

(ただし， $f_{c}: \mathrm{MPa}, \delta_{n}: \mathrm{mm}$ )

なお, 今回の分析では, 骨材最大寸法の影響については, 特に有意な差が認められず, $a_{3}=0$ とした。

次に， $K_{I S T}$ 時のすべり量 $\delta_{t 1}$ についても上記と同様の 方法で実験值をまとめ，これを図一4に示した。デー夕 数は, 図一3より限られたものとなり 23 個であった。 この結果, 最小二乗法による回帰曲線として, 下式を得 た。

$$
\delta_{t 1}=1.42\left(\frac{D_{a}}{16}\right)^{-1.20} \delta_{n}^{1.31}
$$

コンクリート強度についての有意な差は認められず, $a_{6}=0$ とした. 最大せん断強度 $\tau_{u}$ については, 既往の 実験データでは十分な情報が得られず, Bazant, Gambarova $^{5)}$ の実験式をそのまま採用した。すすなわち，

$$
\tau_{u}=\frac{0.01}{0.01+\left(\frac{\delta_{n}}{D_{a}}\right)^{2}} \tau_{0}, \quad \tau_{0}=0.245 f_{c}
$$

以上示した式 (11)〜 (13) で与えられるパラメーター を式（9）に代入することにより，種々の条件下の接線

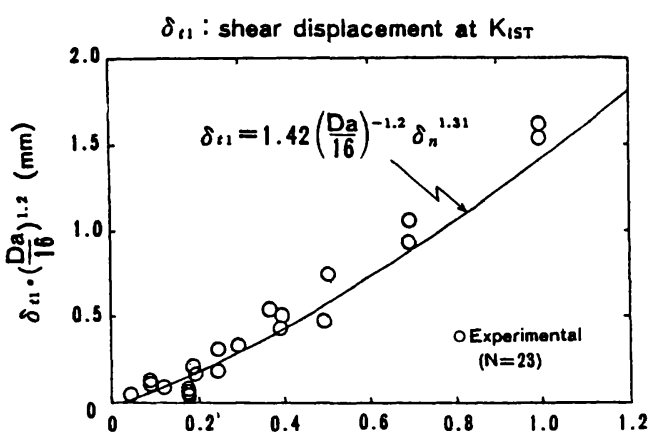

NORMAL DISPLACEMENT $\delta_{\mathrm{n}}(\mathrm{mm})$

図一4 最大せん断剛性時のせん断变位 $\delta_{t 1}$ に関する実験結果の まとめと最小二乗近似による各係数の決定

せん断剛性 $k_{t}$ を求めることが可能となった.

(2) 垂直剛性 $k_{n}$ のモデル化

ひびわれ界面の垂直剛性は, 式 (3) から,

$$
k_{n} \equiv \frac{\partial \sigma_{n}^{c}}{\partial \delta_{n}}=\left.\frac{d \sigma_{n}^{c}}{d \delta_{n}}\right|_{\tau_{n t}^{c}=\text { const. }}
$$

と考えることができる．垂直剛性に関する既往の検討は きわめて数少ないが，図一5のようなモデルを考える. すなわち，ある与えられた初期ひびわれ幅は垂直応力 $-\sigma_{n}^{c}$ (圧縮応力）の増加により， $\delta_{n}=0$ に向かって閉合 していくが，せん断方向に不整合 $\delta_{t}$ があった場合，完 全に閉合することはなく， $\delta_{n}=0$ のかわりに， $\delta_{n}=\delta_{n}^{*}$ を漸近線としたものである.すなわち， $\sigma_{n}^{c} \sim \delta_{n}$ 関係お よび垂直剛性 $k_{n}$ を次式で表現する.

$$
\begin{aligned}
& -\sigma_{n}^{c} / f_{c}=b_{1}\left(\delta_{n}-\delta_{n}^{*}\right)^{-b_{2}} \cdots \\
& k_{n} / f_{c}=b_{1} b_{2}\left(\delta_{n}-\delta_{n}^{*}\right)^{-\left(b_{2}+1\right)}
\end{aligned}
$$

ここで， $b_{1}, b_{2}$ は材料定数を示す. $\delta_{n}^{*}$ は軸圧縮応力に よって閉合しない残留ひびわれ幅を意味する.

次に，仮定した実験曲線式（15）の係数を決定するた め, 実験結果との照合を行った。図一6は, 吉川の行っ たひびわれ界面での垂直載荷試験結果 ${ }^{13)}$ の一部をとりま とめたもので, 初期すべり量 $\delta_{t 0}$ およびコン゙クリート圧 縮強度 $f_{c}$ をパラメーターとしている（また, 載荷中は, せん断応力 $\tau_{n t}^{c}$ を一定にしている).

そして, 一連の実験結果を $-\sigma_{n}^{c} / f_{c} \sim\left(\delta_{n}-\delta_{n}^{*}\right)$ によっ て正規化し，整理・図化した。これらは，残留ひびわれ 幅 $\delta_{n}^{*}$ を実験曲線から読み取り，最小二乗近似により式 （15）の各係数 $b_{1}$ と $b_{2}$ を算出し，実線にて図示したも のである．その結果，実測デー夕群より $b_{1}=0.0082$, $b_{2}=0.878$ を同定し，次式の近似曲線を得ることができ た.

$$
-\sigma_{n}^{c} / f_{c}=8.2 \times 10^{-3}\left(\delta_{n}-\delta_{n}^{*}\right)^{-0.878}
$$

図一6の実験デー夕はややばらつきを呈するが，いずれ も同様の傾向を示すもので，ひびわれ界面でのひびわれ 


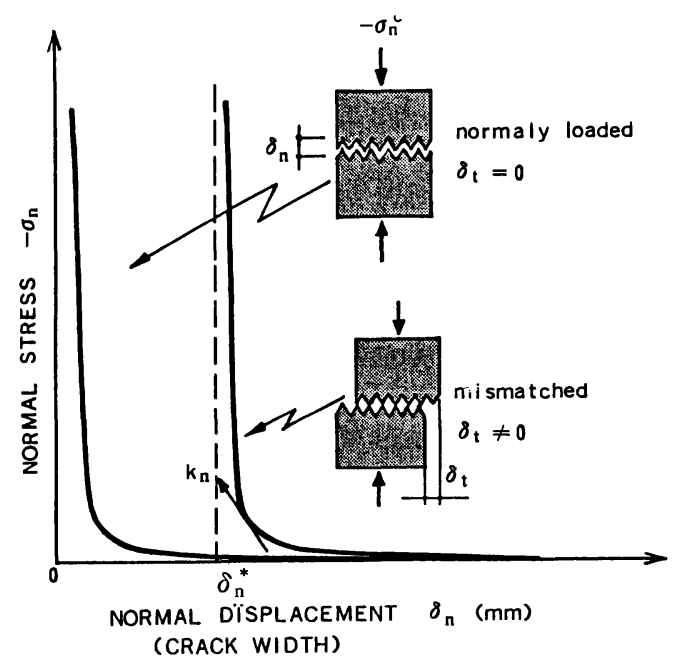

図一5 ひびわれ界面における垂直応力と垂直変位の関係に関す るモデル化

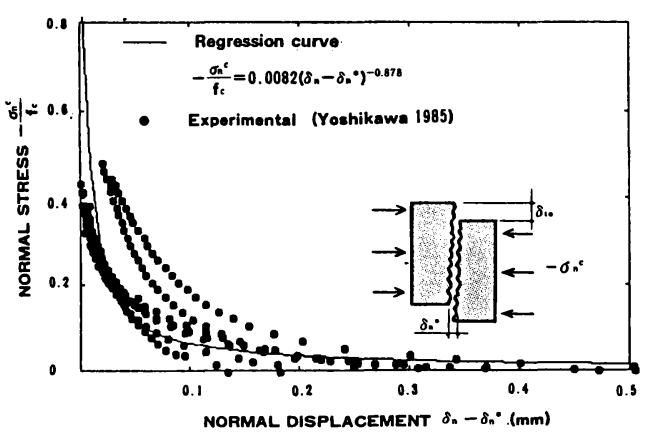

図一6 ひびわれ界面における垂直応力と垂直变位の関係に関す る実験結果と最小二乗法による曲線近似

幅閉合の様子をほぼ近似し得ると考える. 残留ひびわれ 幅がごのような形で定義されるかについてはさらに検討 が必要であるが, ここでは $\delta_{n}^{*}=\beta_{d} \cdot \delta_{t}$ で与えられるもの と仮定する.

(3) 交差係数 $\mu_{f}, \beta_{d}$

交差効果は,ひびわれ界面の特異な非線形性状を特徵 づける重要な役割を担うが, そのモデル化・定量化はき わめて限られたものとなっている.これは, 現象論とし ては認知されていたたとえ(゙10),14)ものの，これらを非対角 項として取り扱う解析手法が完備していなかったこと, ならびに交差係数を同定する際の実験的な困難さに起因 していたものと判断される. そこで, 前述した交差係数 の定義式,

$$
\begin{aligned}
& \mu_{f} \equiv\left(\frac{-\partial \sigma_{n}^{c}}{\partial \tau_{n t}^{c}}\right)^{-1}=\left.\frac{d \tau_{n t}^{c}}{-d \sigma_{n}^{c}}\right|_{o_{n}=\text { const. }} . \\
& \beta_{d} \equiv \frac{\partial \delta_{n}}{\partial \delta_{t}}=\left.\frac{d \delta_{n}}{d \delta_{t}}\right|_{\sigma_{n}^{c}=\text { const. }}
\end{aligned}
$$

に従いこれらに合致する実験を実施することにより， 交差係数を実験的に同定することを試みた。

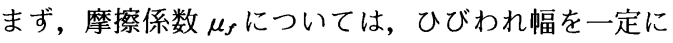
保持した状態でせん断変形を与えたときの, せん断応力 と垂直応力との比を求めればよい, そして, この条件に 合致する実験結果 (吉川 ${ }^{13)}$, Laible ${ }^{15)}$, Paulay $^{4)}$ ) を参照・

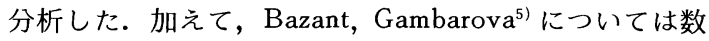
值シミュレーション結果をそのまま引用し, 実験結果の 1 つとみなした。 そして, $-\sigma_{n}^{c} \sim \tau_{n t}^{c}$ 関係がほぼ直線的 でその勾配が $\delta_{n}$ のみに依存すると考え, 摩擦係数 $\mu_{s}$ を 算出した。これらを図一7にプロットするとともに, 最 小二乗近似式

$$
\mu_{f}=1.16 \exp \left(0.61 \delta_{n}\right)
$$

を得た. すなわち, ひびわれ幅の増大とともに摩擦係数 $\mu_{s}$ は增加するもので, このことは $-d \sigma_{n}^{c}=d \tau_{n t}^{c} / \mu_{s}$ が 示すように, あるせん断応力増分に応答する垂直応力 (圧 縮）の増加分が減少することを意味する.

ダイレイタンシー比 $\beta_{d}$ については, 垂直応力を一定 としたときのせん断変形 (すべり量) と垂直変形 (ひび われ幅) の関係を求めればよい，そこで，ひびわれ面直 交方向の垂直応力を一定としたときの直接一面せん断実 験および直接二面せん断実験を実施し, ダイレイタン シー比 $\beta_{d}$ を求めた ${ }^{13)}$.

ダイレイタンシー比 $\beta_{d}$ は, 載荷過程において, 増加 または減少する非線形パラメーターとなることが予想さ れたが, 得られた $\delta_{n} \sim \delta_{t}$ は比較的直線性に富み, 最大 せん断力以降の軟化域においてもほぼ同一の勾配を追随 するもので, $\beta_{d}$ を一定とした. そして, 種々の定垂直 応力 $-\sigma_{n}^{c}$ をパラメーターとし, 対応する $\beta_{d}$ を図一8に 示した.これより, 載荷垂直応力の増加によって $\beta_{d}$ が 減少することが認められ, 次式の近似曲線を得た。

$$
\beta_{d}=1.64 \exp \left(-6.42\left|\frac{\sigma_{n}^{c}}{f_{c}}\right|\right) \cdot
$$

同図は, 垂直応力が作用しないとき, ダイレイタンシー 比は最大となり, 以降, 圧縮垂直応力の増大によりダイ レイタンシー比は 0 に収束する。

以上により，交差係数を実験的に同定することができ たが, ビちらとも比較的大きなばらつきが認められ，図 一7, 8 をみると, 実測デー夕群のばらつきの幅は, 得 られた平均曲線に対して最大 $\pm 50 \%$ にも達することが わかる. 特に, $\mu_{s}$ に対しては研究者ごとによる差異が 認められ, $\beta_{d}$ の場合では圧縮応力 $-\sigma_{n}^{c}$ が小さいほどば らつきが大きいことが特徵的である.

このようなばらつきの原因として, 各供試体の材料条 件, すなわち, 圧縮強度, 骨材寸法, 玉砂利 - 砕石の違 い, 骨材粒度・表面粗度なよ゙が挙げられよう. 加えて, 供試体間のばらつきや, 実験実施の困難さに伴う測定誤 


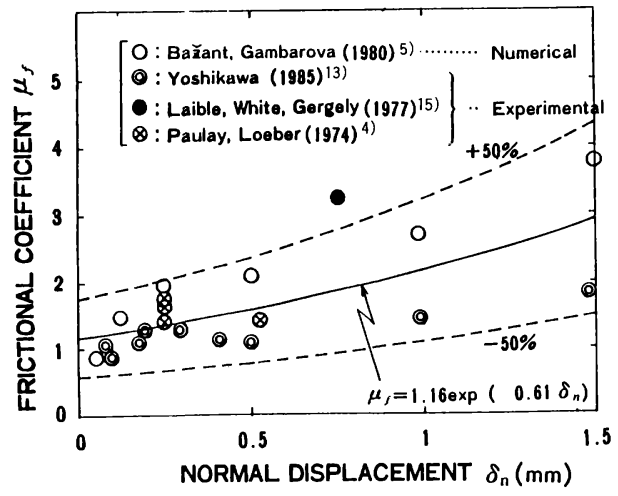

図一7 摩擦係数 $\mu_{f}$ に関する実験結果のまとめと最小二乗法に よる曲線近似

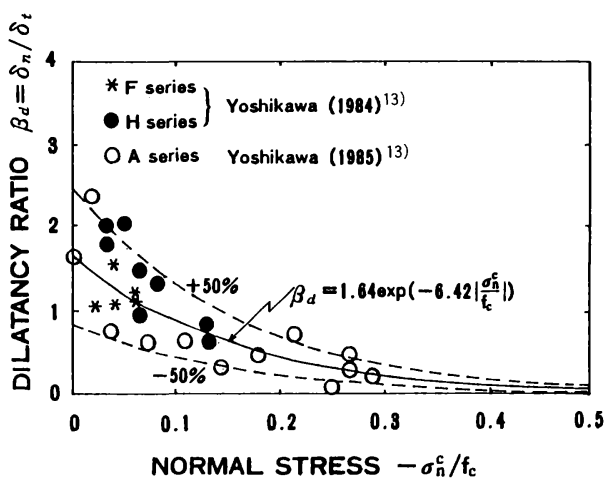

図一8 ダイレイタンシー比 $\beta_{d}$ に関する実験結果のまとめと最 小二乗法による曲線近似

差にも起因することが推察される。したがって，より確 度の高い交差係数を求めるには, さらに広範囲で系統 的・高精度の実験的研究が必要之される.また， $\beta_{d}$ 之 $\mu_{f}$ のおのおのに対して, 本論では 1 つの力学量で表現 しているが, これは必ずしも十分とはいえず，さらにい くつかのパラメーターを加える必要がある.

以上により, 基本 4 係数のモデル化が完了したが, こ こでは式（2）に示した全微分が成立するための必要十 分条件を確認する必要がある。本論では，表一2に提示 した諸係数の提案曲線を用いると式 (2) は不完全微分 となるが, 積分因数を導入することにより完全微分とす ることができる．したがって，式（2）のままで与えら れる力学 4 量については状態量（経路によらず, 始点と 終点のみの状態によって決まる量）ではなく, 積分因数 を適当に定めた場合に状態量となる.このようなことは, 定式化過程における数学的要件と複雑な実現象の忠実な モデル化とが整合性よくかみ合わないことによるもの で，工学上はたびたび遭遇する問題でもあり，現状では やむを得ない措置と考えている.

\section{4. 実験結果との比較}

本提案モデルを既往の諸実験結果にあてはめ,ひびわ れ界面における力学 4 量の非線形挙動について定量的に 考察を行い，本モデルの適応性について検討する.

既往のせん断実験は，通例その境界条件によって，(1) 垂直変位一定，(2)弾性拘束（鋼材または埋設鉄筋による ひびわれ面直交方向の拘束), (3)垂直応力（圧縮）一定 の 3 ケースに大別される.ここで取り上げたのは上記(1) と(2)で，いずれも著名な実験例である.

なお, 数値計算に際しては, 文献 6 ) の表一 2 に示し た増分式を用い，これをパソコンプログラム ${ }^{77,8)}$ により 対象とする実験条件に従って処理した。

\section{（1）垂直変位一定の場合}

垂直変位 $\delta_{n}$ を一定とした場合の実験結果について, 本提案モデルによる解析結果とともに図一 9 に示した. これらは, (a) Paulay, Loeber ${ }^{4)}$, (b) Houde, Mirza ${ }^{111}$, (c), (d) Fenwick, Paulay ${ }^{12)}$, (e), (f) Reinhardt, Walraven ${ }^{10)}$ を引用したもので，いずれもひびわれ幅 $\delta_{n}$ をパラメーターとした実験である，図中では，各プロッ トが実験值を示し，対応する理論值を実線で表わしてい る.

図一9 の実験は，種々の異なる一定ひびわれ幅 $\delta_{n}, コ$ ンクリート圧縮強度 $f_{c}$, 骨材の最大寸法 $D_{a}$ の条件下 30 種類の供試体によるものであるが, 実験値と理論值 は大略合致しているといえる.

\section{（2）弾性拘束の場合}

次いで，ひびわれ界面直交方向に鋼材による外部拘束 または埋設鉄筋があるとき，すなわち，

$$
-d \sigma_{n}^{c}=r_{n} d \delta_{n}
$$

なる剛性 $r_{n}$ をもつ場合について, 実験結果との対比を 行う.そこで, Millard, Johnson ${ }^{14)}$ による合計 9 供試 体について比較検討を行い，これらを図一10に図示し た.これは，埋設鉄筋量と初期ひびわれ幅（0.125 $0.50 \mathrm{~mm})$ をパラメーターとしたもので, 諸条件は脚注 に示したとおりである（本実験は，界面の力学 4 量す心゙ てが測定されている数少ない実験例である).コンクリー 卜に関する圧縮強度と骨材の最大寸法および初期ひびわ れ幅は既知量であったが，埋設鉄筋による拘束係数 $r_{n}$ が明示されていないため,垂直応力と垂直変位の関係( $\sigma_{n}^{c} \sim \delta_{n}$ 関係) から推定した。これは，同図の最下段に 示したもので, 実験值とこれより推定した解析值が当然 のことながらほぼ完全に合致している.

実験值には，初期ひびわれ幅や拘束鉄筋の違いがよく 表われており，解析值も同様の傾向を与えている．実験 值之解析結果は全般的にほぼ合致しているが， $\tau_{n t}^{c} \sim \delta_{t}$ 関係でやや大きな乘離がみられる. 

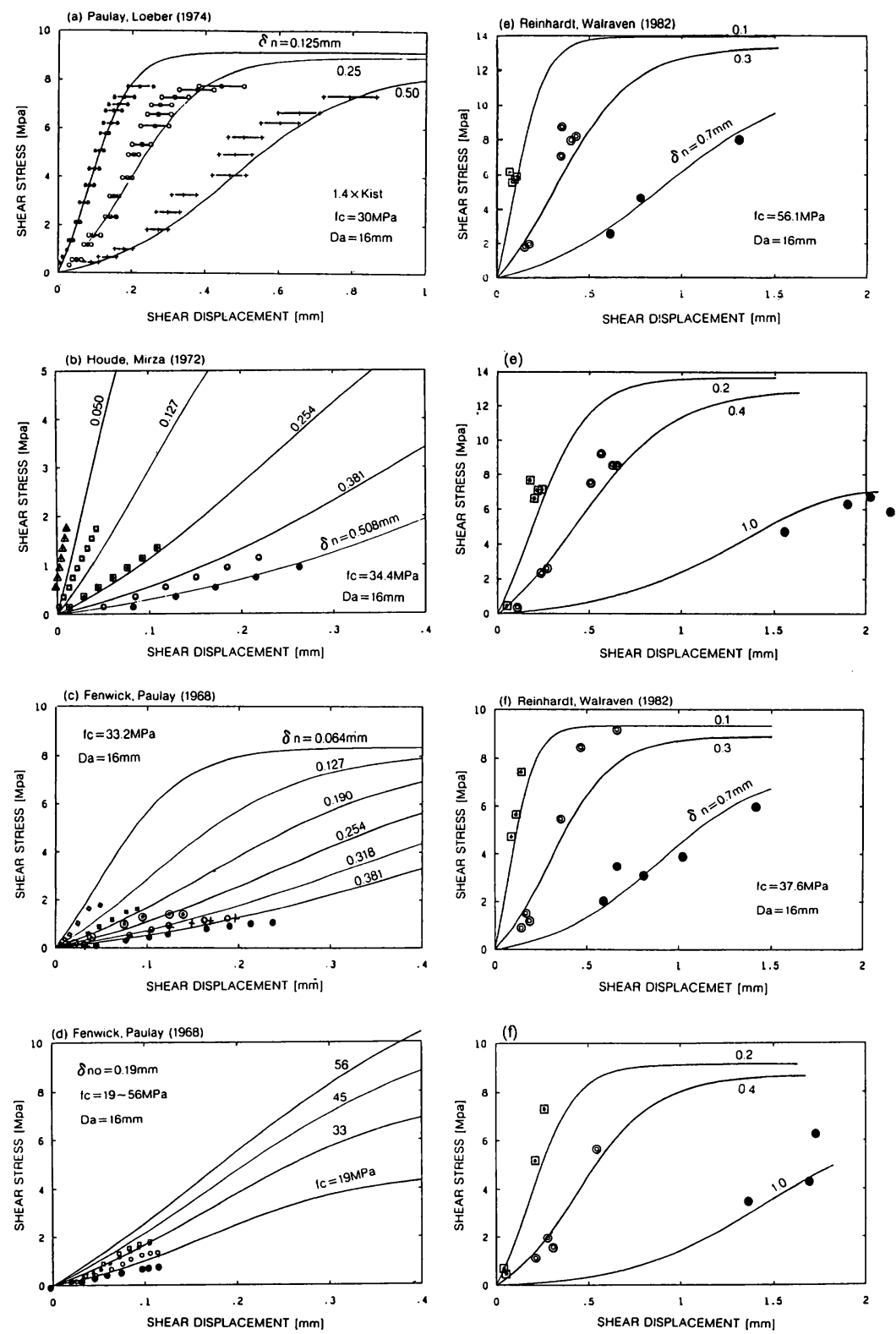

図一9 本提案モデルと実測結果との比較（ひびわれ幅 $\delta_{n}$ 一定の場合）

(a) Paulay, Loeber ${ }^{4}$, (b) Houde, Mirza ${ }^{11)}$, (c) (d) Fenwick, Paulay ${ }^{12)}$, (e) (f) Reinhardt, Walraven ${ }^{10)}$

以上の図一 9,10 で実験值と解析值が十分合致しない 䇢所が若干みられたが，この理由として次項が考えられ る.

(1) 寸法効果：照合した諸実験の供試体は, 種々の異 なる形状寸法を有するもので，寸法効果があったことが 推定される. 特に, せん断応力は, 作用せん断荷重をひ びわれ界面の面積で除した平均公称応力であり, 実際に は加力方向にある分布形をもつことが考えられる.
(2) 交差係数： $\mu_{f}, \beta_{d}$ は, 多くの実験值を用いた最小 二乗法によって同定したが, いずれも $\pm 50 \%$ 程度の大 きなばらつきが認められた（図一7，8）。したがって， 解析値の算定に際しては, これらを適当に調整する必要 がある.このため, $\mu_{f} に$ 対して， $c_{1}=0.5 \sim 1.5 ， \beta_{d}$ に 対して $c_{3}=0.5 \sim 1.5$ の幅をもつ係数を導入したが, た とえば, 図一10の計算では, $c_{1}=1, c_{3}=0.5$ を仮定した.

(3) 骨材粒度, 界面粗度：ひびわれ界面の凹凸による 
Direct Shear Tests by Millard, Johnson (1985)

(a) $1-4-7$
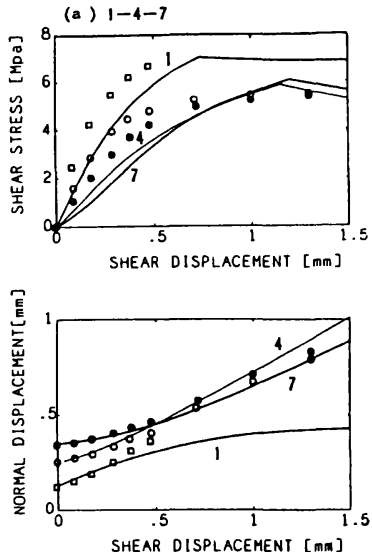

SHEAR DISPLACEMENT [mm]

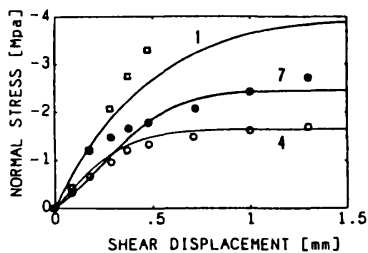

SHEAR DISPLACEMENT [mm]

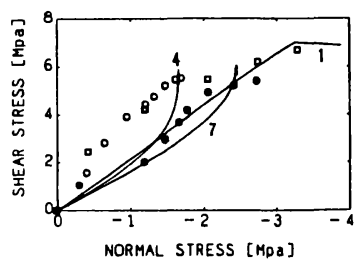

NORMAL STRESS [MPa]

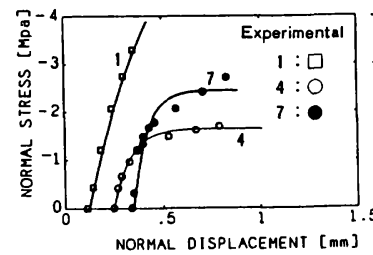

NORMAL DISPLACEMENT [mm]

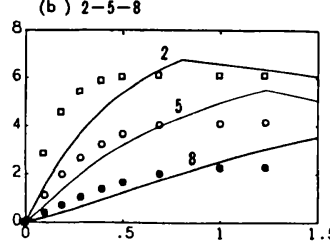

SHEAR DISPLACEMENT [mm]

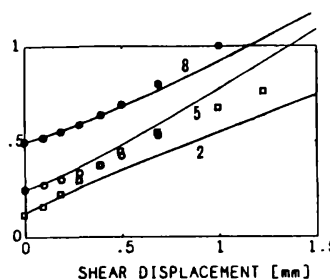

SHEAR DISPLACEMENT [mm]

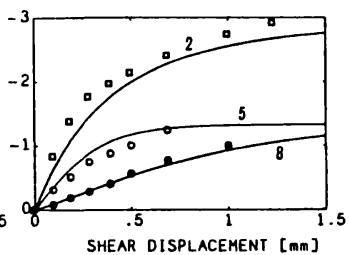

SHEAR DISPLACEMENT [mm]

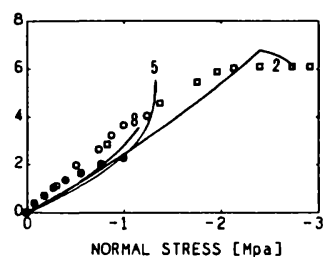

NORMAL STRESS [Mpa]

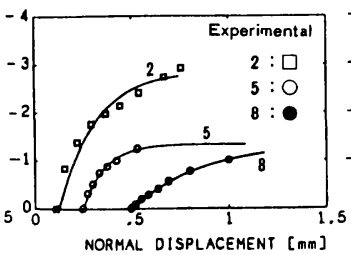

NORMAL DISPLACEMENT [mm]

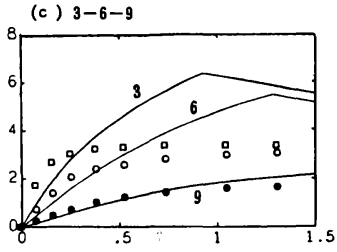

SHEAR DISPLACEMENT [mm]
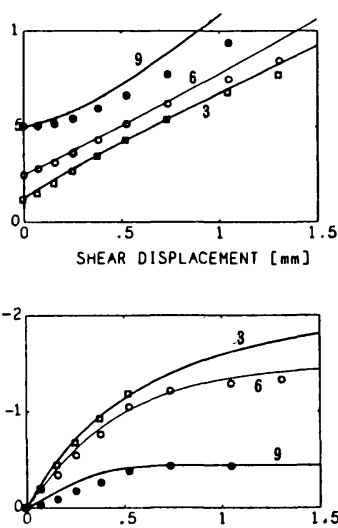

SHEAR OISPLACEMENT [mm]

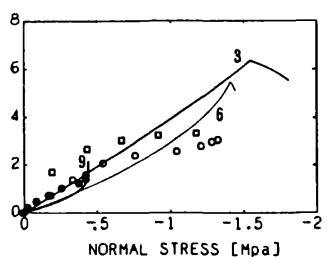

NORMAL STRESS [Mpa]

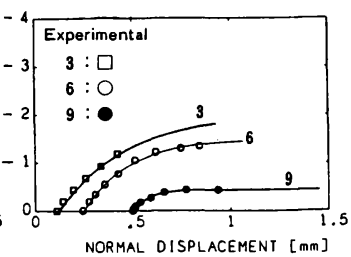

Analytical Condition

\begin{tabular}{|c|c|c|c|c|c|c|c|}
\hline$\xi$ & $a_{12}$ & $c_{1}$ & $c_{3}$ & & crack width $\delta$ & $\mathrm{mm})$ & Concrete \\
\hline \multirow{3}{*}{0.5} & \multirow{3}{*}{0.245} & \multirow{3}{*}{1} & \multirow{3}{*}{0.5} & $\square 1: 0.125$ & $\square 2: 0.125$ & $\square 3: 0.125$ & \multirow{3}{*}{$\begin{array}{l}\mathrm{f}_{c}=30 \mathrm{Mpa} \\
\mathrm{D}_{a}=16 \mathrm{~mm}\end{array}$} \\
\hline & & & & $04: 0.25$ & $\bigcirc 5: 0.25$ & $06: 0.25$ & \\
\hline & & & & $7: 0.35$ & $8: 0.50$ & $9: 0.50$ & \\
\hline
\end{tabular}

図一10 埋設鉄筋を有する場合の本提案モデルと実測結果との比較 (Millard, Johnson $\left.{ }^{14)}, 1-4-7,2-5-8,3-6-9\right)$

粗度を表現するのであるから, 本来ならば骨材の最大寸 法のみならず，骨材の粒度分布と種別なども考慮される べきである（このようなモデル化の例として， Walraven ${ }^{16)}$ がある). すなわち, 本提案モデルのように, 骨材の最大寸法だけではやや不十分であることが予測さ れる.
(4) ダウエル効果：補強鉄筋を埋設した場合, その鉄 筋はせん断方向にも抵抗力をもつ.これは，ダウエル効 果とよばれるが, 本提案モデルではこれを無視しており, このことによりせん断応力を過小評価することが考えら れる. しかしながら, 一般に, 全体のせん断抵抗力に寄 与するダウエル効果の比率は小さく（たとえば, Fen- 
wick, Paulay $\left.{ }^{12)}\right)$, しかもこれまで参照した諸実験の範 囲では外部拘束と埋設鉄筋との差が明確に認められず， ダウエル効果の影響は考えにくい.

\section{5. 結 論}

本文の結論を次のように要約する.

（1）ひびわれ界面におけるせん断挙動は，せん断応 力やせん断すべりが生じる一方で，ひびわれ幅や垂直応 力（压縮応力）の増大などひびわれ直交方向の成分も関 与し, 界面の力学 4 量 $\tau_{n t}^{c}, \sigma_{n}^{c}, \delta_{t}, \delta_{n}$ すべてが干渉し合 う複雑なメカニズムとなる。これは単にせん断剛性のみ ならず，垂直剛性や，さらにはせん断成分と垂直成分の 交差効果を考慮する必要があることを示唆するものであ る、このような界面の非線形挙動を表現するため, 著者 らは, その力学 4 量についての構成方程式を提案した.

（2）基本 4 係数（ $\left.k_{t}, k_{n}, \mu_{f}, \beta_{d}\right)$ を数学的には界面 力学 4 量間の偏導関数として定義したが，これらの実験 式を作り出すには広範囲で系統的な実験的研究が必要と なる．そこで，著者らの実験も含めた国内外の既往主要 実験を参照・整理し, その力学条件（特に境界条件）の 明確な実測結果を抽出し，その実験式を導いた。

（3）せん断剛性 $k_{t}$ は, 基本 4 係数の中で最も重要 なものでこれまで数多くの研究例があり，いわゆるせん 断伝達機構の主動的役割をなす. 本研究では, $k_{t}$ をひ びわれ幅 $\delta_{n}$ が固定された場合のせん断剛性（接線係数） として定義し，これを $K_{I S T}, \delta_{t 1}, \tau_{u}$ をパラメーターとす る双曲線関数でモデル化した。これら 3 パラメーターを 用いた双曲線モデルにより, 初期 $\left(\delta_{t}<\delta_{t 1}\right)$ での比較的 ルーズなすべり，その後の剛性復活 (interlocking), $\tau_{u}$ に向かう頭打ちなどの特徴的な骨材のかみ合い効果を 1 つの式で表現することができる．そして，多くの実験結 果のうち, 境界条件が本定義と合致するもの(すなわち, $\delta_{n}=$ 一定の場合）を引用し， $k_{t}$ についての実験モデル の各係数を同定した.

（4）垂直剛性 $k_{n}$ は， $k_{t}$ とともに構成則の対角項に 位置する重要な剛性であるが, これまでせん断伝達が主 たる論点であったことから，ほとんど検討されることが なく，実験例も少ない，また，垂直剛性はひびわれ界面 の閉合・再接触の判定にも重要となるばかりでなく，境 界条件によってはせん断剛性にも間接的に影響を与え る.

そこで, 初期すべり量 $\delta_{t 0}$ をパラメーターとし，ひび われ面垂直方向の圧縮試験を行い, $-\sigma_{n}^{c} \sim \delta_{n}$ の関係を 測定した。このような実験から，圧縮応力下の垂直応力 とひびわれ幅の関係 $\left(-\sigma_{n}^{c} \sim \delta_{n}\right.$ 曲線 $)$ を指数関数で近 似する実験式を求めた．このときのひびわれ幅は， $\delta_{n}=$ 0 に向かって閉合するのではなく，すべりが生じていた
場合は $\delta_{n}^{*}=\beta_{d} \cdot \delta_{t}$ を残留ひびわれ幅とし，この値を漸近 值とした.これは, 実施した 6 体の供試体の試験結果す べてを 1 個の実験式でほぼ近似し得るものである.

（5）ダイレイタンシー比 $\beta_{d}$ と摩擦係数 $\mu_{f}$ は非対角 項に位置するとともに，ひびわれ界面における特徴的な 交差効果を表わす不可欠な係数である。このような交差 効果に関する非線形現象は，これまで実験的には認知さ れていたものの, これらを数式モデルに取り込んだり， 実験式を求めようとする研究は散見されるに過ぎない.

摩擦係数 $\mu_{f}$ は, 著者らの定義から, ひびわれ幅 $\delta_{n}$ を 一定に保持したときの界面応力 $\left(\tau_{n t}^{c}\right.$ と $\left.-\sigma_{n}^{c}\right)$ の比であ る.このような要件を満たす 3 例の実験結果と 1 例の数 值計算結果を同一図上にプロットし， $\delta_{n}$ を関数とする 実験式を最小二乗近似によって同定した。

一方，ダイレイタンシー比 $\beta_{d}$ は，著者らの定義から， 垂直応力（压縮）を一定としたときの界面変位量の比 $\left(\delta_{n} / \delta_{t}\right)$ に相当する.このような条件の実験例は，コ ンクリート材料ではほとんゼみられず, 著者らが実施し た一面せん断と二面せん断実験をもとに実験式を算定し た.この場合は，ダイレイタンシー比は一定垂直応力を 引数よする指数関数で表現し, 諸係数を実験結果より最 小二乗近似で求めた.

ただし，実験結果はかなりのばらつきを呈し，両係数 とも, 求めた実験曲線の $\pm 50 \%$ にもおよぶことがわかっ た.これは提案モデルの実験パラメーターの不足や実験 テクニックの困難さ，もしくは実験結果に対する影響因 子が不十分であったことによるものと推察される.この ためには, さらに広範囲かつ高精度の実験的検証および モデル化の再検討が必要とされる.

（6）最後に, 既往実験の実験結果に本提案モデルを あてはめ, その解析精度について検討した。ここでは, 垂直変位一定の場合および弾性拘束の場合による実験結 果を引用した．両ケースの場合とも，若干の差異はある ものの, 実験値と解析結果は全般的に合致し, 本提案モ デルは, 工学上ほぼ十分な予測精度を有するものと判断 される. 一方, 実験結果と解析結果とは若干の乘離が認 められたが, この理由として, 供試体の形状・寸法の違 い, 交差係数のばらつき, 回転変位の混入, 骨材粒度分 布やダウエル効果を考慮していないことなどが挙げられ る.

\section{参 考 文 献}

1) The Task Committee on Finite Element Analysis of Reinforced Concrete Structures of the Structural Division Committee on Concrete and Masonry Structures: State-of-the-Art Report on Finite Element Analysis of Reinforced Concrete, ASCE, New York, 1981.

2) Buyukozturk, O., Connor, J. J. and Leombruni, P. : 
Research on Modeling Shear Transfer in Reinforced Concrete Nuclear Structures, Nuclear Engineering and Design, Vol.59, No.1, pp. 67 83, August 1980.

3) Goodman, R.E. and Dubois, J. : Duplication of Dilatancy in Analysis of Jointed Rocks, Journal of the Soil Mechanics and Foundations Division, ASCE, Vol.98, No. SM 4, pp.399 422, April, 1972.

4) Paulay, T. and Loeber, P. J. : Shear Transfer by Aggregate Interlock, SP 42, American Concrete Institute, pp. 1 15, 1974.

5) Bazant, Z.P. and Gambarova, P. : Rough Cracks in Reinforced Concrete, Journal of the Structural Division, ASCE, Vol. 106, No. ST 4, pp. 819 842, April, 1980.

6）吉川弘道・田辺忠顕：コンクリート部材のひびわれ界面 における力学的挙動に関する解析的研究, 土木学会論文 集, No. 372/V-5, pp.101 110，1986.8.

7) 吉川弘道・田辺忠顕：ひびわれ界面の力学挙動（Fモ一 ドひびわれ）に関する解析モデル, 土木学会第 41 回年次 学術講演会, pp. 237〜238, 1986. 11.

8）石井賢史·吉川弘道・田辺忠顕：F モードひびわれの数 值解析とそのパソコンプログラム, 土木学会第 41 回年次 学術講演会, pp.239 240, 1986. 11.

9）山田一宇：鉄筋コンクリート製原子炉格納容器の設計に おける問題点, 特に RC シェル要素のせん断設計法の合 理化に関する研究, 前田建設技術研究所報, No. 22-1, 1982. 3 .
10) Reinhardt, H.W. and Walraven, J. C. : Cracks in Concrete Subject to Shear, Journal of the Structural Division, ASCE, Vol. 108, No. ST 1, pp. 207 224, Jan., 1982.

11) Houde, Mirza (1972), 文献 1) の chapter 5 より参照し た.

12) Fenwick, R. C. and Paulay, T. : Mechanisms of Shear Resistance of Concrete Beams, Proceedings of the American Society of Civil Engineers, Vol. 94, No. ST 10, pp. 2325 2350, October, 1968.

13）吉川弘道：面内力を受ける鉄筋コンクリート部材の力学 的挙動に関する解析モデル, 東京大学学位論文, 1986.6.

14) Millard, S. G. and Johnson, R. P. : Shear Transfer in Cracked Reinforced Concrete, Magazine of Concrete Research, Vol. 37, No. 130, pp. 3 15, March, 1985.

15) Laible, J.P., White, R. N. and Gergely, P. : Experimental Investigation of Shear Transfer Across Cracks in Concrete Nuclear Containment Vessels, SP 53, American Concrete Institute, pp. 203 226, 1977.

16) Walraven, J.C. : Fundamental Analysis of Aggregate Interlock, ASCE, Vol. 107, No. ST 11, pp. 2245 2270, November, 1981.

17）たとえば, 小出昭一郎：物理と微積分, 共立出版, p. 106, 1981. 10.

(1988. 7.28 - 受付) 